\title{
Sosialisasi Perubahan Peran Orang Tua Pada Masa Pandemi Covid-19 Sebagai Bentuk Dukungan Pelaksanaan Learning From Home
}

\author{
Eny Kusumawati \\ Universitas Tunas Pembangunan Surakarta \\ enylajanu86@gmail.com
}

\begin{abstract}
Every parent needs to have an understanding of the implementation of learning from home as a result of the Covid-19 pandemic, where there has been a change in the role that was originally carried out in the education unit has now changed in the family unit. This socialization activity aims to provide knowledge and understanding to parents of the importance of the role of parents during the Covid-19 pandemic as a form of support for the implementation of learning from home. This service activity was carried out in Dusun Kembang, Margosari, Pengasih with as many as 30 participants selected based on the presence or absence of school-age children in their household. This service activity is designed in three stages: (1) the planning stage begins with the need assessment, (2) the activity or implementation stage, (3) the activity evaluation stage. From the results of the evaluation, it can be concluded that (1) the socialization of changes in the role of parents during the Covid-19 pandemic as a form of support for the implementation of learning from home is very beneficial for parents, (2) parents have an understanding of the importance of the role of parents in accompanying children to learn at home.
\end{abstract}

Keywords: role of parents; Covid-19; learning from home

\begin{abstract}
Abstrak
Pemahaman tentang pelaksanaan learning from home perlu dimiliki oleh setiap orang tua sebagai akibat dari pandemi covid-19 dimana telah terjadi perubahan peran yang semula dilakukan di satuan pendidikan kini berubah di satuan keluarga. Kegiatan sosialisasi ini bertujuan untuk memberikan pengetahuan dan pemahaman kepada orang tua akan pentingnya peran orang tua dimasa pandemi covid-19 sebagai bentuk dukungan pelaksanaan learning from home. Kegiatan pengabdian ini dilaksanakan di Dusun Kembang, Margosari, Pengasih dengan peserta sebanyak 30 warga yang dipilih berdasarkan ada atau tidaknya anak usia sekolah dalam rumah tangga mereka. Kegiatan pengabdian ini dirancang dalam tiga tahap: (1) tahap perencanaan diawali dengan need assesment, (2) tahap kegiatan atau pelaksanaan, (3) tahap evaluasi kegiatan. Dari hasil evaluasi dapat disimpulkan bahwa (1) kegiatan sosialisasi perubahan peran orang tua pada masa pandemi covid-19 sebagai bentuk dukungan pelaksanaan learning from home sangat bermanfaat bagi orang tua, (2) orang tua memiliki pemahaman akan pentingnya peran orang tua dalam mendampingi anak belajar di rumah.
\end{abstract}

Kata Kunci: peran orang tua; covid-19; learning from home

\begin{tabular}{l|l|l} 
Submitted: 2021-08-12 & Revised: 2021-10-11 & Accepted: 2021-10-26
\end{tabular}

\section{Pendahuluan}

Menanggapi wabah Covid-19, berbagai upaya telah dilakukan guna mencegah penularan virus tersebut. Penguncian (lockdown), jaga jarak (social distancing), dan pergeseran format pembelajaran, serta faktor ekonomi dan kontekstual lainnya telah meningkatkan kekhawatiran orang tua karena adanya tuntutan untuk menyesuaikan diri sesuai dengan format tersebut serta kebutuhan individu peserta didik. Sekolah adalah pusat aktivitas sosial dan interaksi manusia. Saat sekolah tutup, banyak anak-anak dan remaja kehilangan kontak sosial yang penting untuk belajar dan mengembangkan diri (Union, 2020). Hal tersebut memiliki efek langsung dan efek jangka panjang, terutama bagi masyarakat yang lebih rentan dan kurang beruntung. Aplikasi komunikasi online (WhatsApp, radio, televisi, ponsel, komputer dan perangkat keras jaringan, sistem satelit) serta berbagai layanan yang tersedia dapat dimanfaatkan oleh peserta didik dalam mengikuti proses pembelajaran jarak jauh. Berbagai aplikasi komunikasi tersebut digunakan untuk memastikan terjadinya komunikasi antara guru dan siswa serta antar siswa dalam banyak hal. Kelas online interaktif juga memberikan kesempatan untuk bersosialisasi interaksi dan 
memfasilitasi kelangsungan pendidikan untuk semua melalui pembelajaran jarak jauh. Banyaknya inisiatif/inovasi dalam pembelajaran ini dianggap sesuai untuk memenuhi kebutuhan. Namun, hal itu juga memberikan rutinitas yang berat bagi para orang tua yang bekerja dari rumah dan sekaligus mengambil tanggung jawab bahwa proses belajar anak-anaknya berlanjut dengan mulus selama masa COVID-19.

Perubahan yang ditimbulkan oleh pandemi COVID-19 dilaporkan telah mempengaruhi keadaan kesejahteraan dan suasana hati para orang tua, serta perilaku anak-anak mereka. Dalam studi yang dilakukan di berbagai negara selama periode pandemi, partisipan menyatakan adanya peningkatan stres psikologis tingkat sedang hingga parah, perubahan suasana hati dan perilaku anak-anak, dan praktik pengasuhan yang memburuk (Duraku, et al., 2020; Wang, et al., 2020). Khususnya dalam pembelajaran dari rumah (learning from home), kekhawatiran utama orang tua diakibatkan kurangnya pengalaman dalam mendukung anak-anak mereka dengan pembelajaran jarak jauh (online), kurangnya akses ke teknologi, dan kendala ekonomi (UNESCO, 2020).

Universitas Tunas Pembangunan Surakarta merupakan salah satu perguruan tinggi yang beralamatkan di Cengkik No. 31 Banjarsari Surkarta. Disini terdapat 5 SD, 1 SMP dan 2 SMA, dan dari wawancara awal yang pengabdi lakukan kepada beberapa orang masyarakat Desa Margosari dan guru di persekolahan melalui telepon, fenomena kekhawatiran masyarakat terutama orang tua yang memiliki siswa di bangku sekolah telah terjadi sejak mulai diberlakukannya learning from home (belajar dari rumah). Terjadinya fenomena kekhawatiran masyarakat terhadap format adaptasi peran baru, mendorong UTP untuk memberikan kontribusi guna menyelesaikan permasalahan yang muncul di masyarakat Desa Margosari, utamanya Dusun Kembang yang letaknya paling dekat dengan perguruan tinggi. Konstribusi yang diberikan yaitu dengan melaksanakan kegiatan pengabdian masyarakat dengan tema sosialisasi perubahan peran orang tua pada masa pandemi covid sebagai bentuk dukungan pelaksanaan learning from home. Hal tersebut seperti direkomendasikan oleh Wang, et al (2020), bahwa orang tua harus diajari intervensi tentang bagaimana memberikan dukungan emosional kepada anak-anak pada saatsaat ketidakpastian (masa pandemi Covid-19). Sejak pandemi dimulai, orang tua sekarang mengambil peran yang lebih berorientasi pada dukungan yaitu mendukung anak-anak mereka saat mereka mengerjakan tugas dan proyek rumah.

Penelitian Emerson (Nash, et al., 2020) menunjukkan bahwa orang tua / pengasuh yang terlibat dalam hasil pembelajaran di rumah dapat memfasilitasi perubahan positif dalam prestasi akademik anak, serta perkembangan dan kesejahteraan mereka. Menurut Hoover-Dempsey et al (2005), faktor-faktor yang mempengaruhi kemampuan orang tua untuk berkontribusi secara aktif pendidikan anak dipengaruhi oleh empat konstruksi: 1) konstruksi peran orang tua yang dibentuk oleh keyakinan, persepsi dan pengalaman orang tua; 2) permintaan/ajakan dari guru dan sekolah pada orang tua untuk menjadi peserta aktif dalam pendidikan anak-anaknya; 3) status sosial ekonomi orang tua yang mempengaruhi ketersediaan keterampilan, pengetahuan, tenaga dan waktu orang tua; dan 4) efikasi diri serta kepercayaan diri yang diperoleh orang tua dari menjadi peserta aktif. Peran orang tua selama pelaksanaan learning from home antara lain: 1) keterlibatan dan pengawasan. Pengawasan orang tua melibatkan bagaimana orang tua memantau anakanaknya, sedangkan keterlibatan orang tua secara luas didefinisikan sebagai perilaku, nilai, sikap, dan aktivitas orang tua yang bertujuan mengembangkan akademis anak, kemampuan untuk belajar dan hasil pembelajaran (Department of Education and Training [Australian Government], 2015).; 2) memberikan semangat dan motivasi kepada anak, 3) membimbing anak dalam bermain dan belajar, 4) menjadi panutan yang baik, 5) menjalin komunikasi yang lancar dengan anak, 6) mengamati dan mengontrol apa yang dilakukan anak; 7) mengenali kesulitan anak dalam bermain dan belajar; dan 8) Orang tua dapat mengajari anak mereka sesuatu yang tidak didapat anak di sekolah, yaitu tentang kecakapan hidup (Hewi \& Asnawati, 2020). Ini bisa dilakukan dengan 
mengajak anak membuat mainan atau belajar mandiri, mengenal diri sendiri, mengekspresikan perasaan, serta menumbuhkan jiwa wirausaha mereka sejak dini.

\section{Metode}

Kegiatan Pengabdian Kepada Masyarakat dengan tema sosialisasi perubahan peran orang tua pada masa pandemi Covid-19 sebagai bentuk dukungan pelaksanaan learning from home, dalam teknisnya dilaksanakan sebagai berikut:

Waktu dan Tempat Pelaksanaan Kegiatan Pengabdian ini sebagai bentuk dukungan pelaksanaan learning from home dilaksanakan selama 3 minggu dan berlangsung disalah satu rumah warga yang dianggap luas

Alat dan Bahan: Alat dan bahan yang digunakan dalam kegiatan ini antara lain materi powerpoint sebagai media presentasi, contoh video kasus permasalahan orang tua, OHP dan layarnya, angket kuesioner, dan sound system.

Langkah Pelaksanaan: Kegiatan pengabdian kepada masyarakat ini diawali dengan cara wawancara langsung terhadap mitra yang menjadi peserta pengabdian. Selama kegiatan pengabdian, semua pelaksana dan peserta selalu menerapkan protokol pencegahan virus Covid19, oleh karena itu wawancara dilakukan via telepon dan Whatsapp (WA). Wawancara awal dilakukan terhadap 10 orang warga masyarakat Desa Cengklik dan 5 orang guru SD, dan 1 orang guru SMP serta 2 guru SMA. Tahap kedua yaitu perencanaan, setelah didapatkan hasil analisis awal dan jenis permasalahan yang ada, pengabdi menawarkan solusi penyelesaian permasalahan mitra dan menentukan subjek yang akan menerima solusi permasalahan. Jumlah peserta pengabdian adalah 30 orang warga Dusun Kembang yang dipilih berdasarkan ada atau tidaknya anak usia sekolah dalam rumah tangga mereka. Tahap ketiga yaitu kegiatan inti berupa pelaksanaan pengabdian. Metode pelaksanaan pengabdian ini adalah pendidikan masyarakat dengan cara memberikan sosialisasi. Metode pelaksanaan, yaitu sosialisai pada masyarakat tentang perubahan peran orang tua pada masa pandemi Covid-19 sebagai bentuk dukungan pelaksanaan learning from home. Tahap keempat atau terakhir yaitu evaluasi pelaksanaan program di lapangan setelah kegiatan ini selesai dilaksanakan.

\section{Hasil dan Pembahasan}

Pelaksanaan kegiatan pengabdian berupa sosialisasi sebagai bentuk dukungan pelaksanaan learning from home dilaksanakan selama 3 minggu (satu minggu wawancara dan 2 minggu pelaksanaan kegiatan inti), yaitu peserta pengabdian sejumlah 30 orang.

Tahap awal pelaksanaan kegiatan pengabdian diawali dengan analisis situasi. Dari hasil wawancara didapatkan informasi bahwa setelah mulai diberlakukannya learning from home (belajar dari rumah) muncul banyak keluhan dari orang tua siswa terkait dengan kesulitan mereka untuk menyesuaikan diri sesuai peran yang dibutuhkan dalam format baru pembelajaran. Informasi yang telah diperoleh dari wawancara kemudian dirapatkan oleh Tim Pengabdi untuk ditentukan solusi yang dapat menyelesaikan permasalahan tersebut.

Tahap kedua pelaksanaan pengabdian atau perencanaan. Pada tahap ini Tim Pengabdi kembali ke lapangan untuk menawarkan solusi, yaitu sosialisasi kepada masyarakat tentang perubahan peran orang tua pada masa pandemi Covid-19 sebagai bentuk dukungan pelaksanaan learning from home. Dari diskusi yang dilakukan pengabdi dengan mitra, maka diperoleh kesepakatan untuk melaksanakan sosialisasi tersebut. Pada tahap ini ditentukan jumlah peserta pengabdian yang disaring berdasarkan ada atau tidaknya anak usia sekolah dalam rumah tangga mereka. Dari hasil penyaringan, jumlah peserta pengabdian ada sejumlah 30 orang, dan dibagi menjadi 3 kelompok sosialisasi guna menghindari pengumpulan massa. Tahap ketiga atau pelaksanaan kegiatan inti. Pada tahap ini, sosialisasi dilaksanakan dalam 3 kali pertemuan. Selama 
kegiatan sosialisasi Tim Pengabdi didampingi Tim Relawan Tanggap Covid-19. Posko Satgas Covid19 dalam pelaksanaan sosialisasi dilakukan secara terbatas dengan tetap menjaga jarak dan menggunakan masker. Secara umum kegiatan diskusi berlangsung sangat baik. Peserta sangat antusias dan bersungguh-sungguh mengikuti sesi demi sesi sajian materi pengabdian yang disajikan oleh narasumber. Demikian pula kegiatan diskusi berlangsung sangat baik. Respon peserta maupun tanggapan dari narasumber berlangsung baik. Banyaknya pertanyaan yang muncul dari peserta menunjukkan adanya respon positif dari peserta terhadap materi pengabdian, disamping juga menunjukkan bahwa banyak hal yang masih perlu dipahami dan dimengerti tentang perubahan peran orang tua guna menyesuaikan diri dengan perubahan format pembelajaran.

Tahap terakhir atau keempat yaitu evaluasi. Evaluasi diadakan setelah kegiatan sosialisasi pada masing-masing sesi kelompok selesai dilaksanakan. Evalusi kegiatan PPM dilakukan dengan memberikan angket respon kepada peserta pengabdian yaitu sebanyak 30 orang peserta pengabdian. Berikut ini adalah hasil rangkuman dari angket respon untuk mengevaluasi program kegiatan PPM: 1) Sebanyak 63,3\% responden menyatakan bahwa materi yang disajikan dalam kegiatan PPM masuk dalam kategori baik, sedangkan sisanya 36,7\% responden menganggap materi yang disajikan masuk ke dalam kategori sangat baik; 2) 93,3\% responden memberikan respon yang sangat baik terhadap kegiatan PPM, sedangkan 6,7\% memberikan respon baik terhadap kegiatan PPM; 3) sebanyak 46,7 \% responden menyatakan bahwa materi yang disajikan dalam PPM sangat berhubungan dengan kebutuhan mereka, sedangkan 53,3\% responden menyatakan bahwa materi yang disajikan pada PPM berhubungan dengan kebutuhan mereka. Dari hasil tersebut dapat katakan bahwa lebih dari $75 \%$ responden/peserta pengabdian menyatakan bahwa materi yang disajikan pada kegiatan PPM berhubungan dengan kebutuhan mereka; dan 4) sebanyak $83,3 \%$ responden menyatakan bahwa minat mereka terhadap kegiatan PPM adalah baik, sedangkan sisanya sebanyak $16,7 \%$ menyatakan bahwa minat mereka terhadap kegiatan PPM adalah sangat baik.

Merebaknya virus Covid-19 mengharuskan orang tua memahami adanya perubahan peran terutama dalam pelaksanaan pembelajaran jarak jauh. Pembelajaran jarak jauh atau sering disebut juga pembelajaran online adalah suatu sistem atau konsep pendidikan yang diselenggarakan dengan memanfaatkan teknologi informasi guna mentransfer pengetahuan dari guru kepada peserta didik (Harahap, 2020). Kebijakan pemerintah yang mengharuskan learning from home merubah peran orang tua yang awalnya dilakukan di satuan pendidikan kini berubah di satuan keluarga (Wardani \& Ayriza, 2020). Orang tua mempunyai peran membantu dan memfasilitasi proses pembelajaran bagi putra-putrinya, walaupun hal itu tidak mudah dan tidak selalu dapat berjalan dengan baik sesuai harapan (Yuliawan, 2016). Disisi lain orang tua dituntut mendukung keberhasilan dari program learning from home yang telah ditentukan oleh pihak sekolah. Wiresti (2020) menyebutkan adanya berbagai hambatan yang dialami oleh para orang tua dalam mendukung keberhasilan dari program learning from home diantaranya adalah (1) pembelajaran daring mengharuskan peserta didik memiliki memiliki perangkat elektronik minimal berupa smartphone, (2) orang tua harus menjamin gizi anak agar tidak mengalami stunting ditengahtengah kesulitan ekonomi keluarga, (3) keberhasilan pembelajaran jarak jauh tergantung pada guru, orang tua, peserta didik, alat pembelajaran, dan konektivitas internet, (4) orang tua memiliki keterbatasan pengetahuan yang terkait dengan materi pelajaran yang diberikan oleh guru.

Berdasarkan berbagai hambatan tersebut menjadi pijakan bagi Tim Pengabdi untuk melakukan sosialisasi dengan mengambil tema perubahan peran orang tua pada masa pandemi Covid-19 sebagai bentuk dukungan pelaksanaan learning from home. Berdasarkan evaluasi dari hasil sosialisasi tersebut menunjukkan bahwa sebanyak 63,3\% responden menyatakan bahwa materi yang disajikan dalam kegiatan PPM masuk dalam kategori baik, sedangkan sisanya 36,7\% responden menganggap materi yang disajikan masuk ke dalam kategori sangat baik. Hal itu sesuai 
dengan hasil penelitian yang dilakukan oleh (Wardani \& Ayriza, 2020) yang menyatakan bahwa jika orang tua memiliki pemahaman materi yang luas maka akan sangat dirasakan manfaatnya dalam mendampingi dan membantu anak belajar di rumah. Orang tua yang terlibat dalam kegiatan PPM ini merasakan kebermanfaatannya hal itu sesuai dengan hasil evaluasi yang menyatakan sebanyak $75 \%$ responden/peserta pengabdian merasakan bahwa materi yang disajikan pada kegiatan PPM berhubungan dengan kebutuhan mereka.

Hasil ini menunjukkan bahwa ada kesesuaian dengan need assessment yang dilakukan oleh Tim Pengabdi pada tahap perencanaan. Adanya kesesuaian dengan need assessment menjadi pendukung terwujudnya kegiatan PPM yang berhasil. Keberhasilan kegiatan PPM ini tidak terlepas dari peran orang tua sebagai peserta kegiatan yang berminat dan berpartisipasi aktif selama kegiatan sosialisasi berlangsung dimana dari hasil evaluasi didapatkan data bahwa sebanyak $83,3 \%$ responden menyatakan bahwa berminat terhadap kegiatan PPM ini. Kegiatan pengabdian kepada masyarakat merupakan salah satu kegiatan tri dharma perguruan tinggi yang memiliki fungsi untuk memberikan pengetahuan, dan pemahaman serta meningkatkan keterampilan bagi masyarakat sebagai bekal dalam menjalankan kehidupan sehari-hari sehingga nantinya terjadi perubahan pada diri sendiri maupun lingkungan sekitar (Trisnani, 2020). Orang tua yang mengetahui dan memahami akan perannya dalam pelaksanaan learning from home akan mengetahui manfaatnya yang dirasakan pula oleh anak diantaranya adalah: (1) anak merasa tidak sendiri, (2) orang tua sebagai pemberi semangat bagi anak, (3) orang tua memfasilitasi kebutuhan anak, (4) orang tua sebagai tempat berdiskusi dan bertanya, (5) orang tua membantu mengenali diri sendiri, (6) orang tua dapat melihat dan mengembangkan bakat anak, (7) orang tua membantu menciptakan lingkungan yang kondusif untuk belajar (Iftitah \& Anawaty, 2020).

\section{Kesimpulan}

Sisi lain pandemi telah memberikan kesempatan bagi semua stakeholder memikirkan kembali fokus pendidikan yang ingin dicapai tentang apa, bagaimana, dan di mana pembelajaran berlangsung, termasuk hubungan antara guru dan orang tua. Ini adalah waktu bagi seluruh komponen pendidikan untuk saling belajar dan membantu. Dari kegiatan yang telah dilaksanakan maka dapat disimpulkan bahwa kegiatan pengabdian berlangsung dengan lancar dan bermanfaat memberikan kontribusi pengetahuan dan pemahaman bagi masyarakat, terutama bagi masyarakat yang menerima manfaat dari kegiatan pengabdian ini khususnya Desa Cengklik yang masih memiliki anak usia sekolah agar dapat menyesuaikan diri sesuai format peran yang dibutuhkan guna menunjang/mengoptimalkan pelaksanaan program belajar dari rumah (learning from home).

Dari hasil evaluasi, maka kedepannya diperlukan adanya pengabdian masyarakat lanjutan terutama untuk masyarakat secara lebih luas serta perlu adanya kemitraan dengan pihak lain dalam mengembangkan model sosialisasi yang lebih terbuka, sehingga mampu memberikan manfaat dan dampak bagi masyarkat luas.

\section{Daftar Pustaka}

Department of Education and Training, Australian Government. (2015). Making my school better. Retrieved from https://docs.education.gov.au/system/files/doc/other/making myschoolbetter.pdf.

Duraku, Z. H. \& Hoxha, L. (2020). The impact of COVID-19 on higher education: A study of interaction among students' mental health, attitudes toward online learning, study skills, and changes in students' life.

Harahap, R. (2020). Fenomena Online learning di masa pandemi. 5(2), 146-156. http://jurnal.umtapsel.ac.id/index.php/Linguistik. Hewi, L., \& Asnawati, L. (2020). Strategi Pendidik Anak 
Usia Dini Era Covid-19 dalam Menumbuhkan Kemampuan Berfikir Logis. Jurnal Obsesi: Jurnal Pendidikan Anak Usia Dini, 5(1), 158-167. https://doi.org/10.31004/obsesi.v5i1.530.

Iftitah, S. L., \& Anawaty, M. F. (2020). Peran Orang Tua Dalam Mendampingi Anak Di Rumah Selama Pandemi Covid-19. JCE (Journal of Childhood Education), 4(2), 71. https://doi.org/10.30736/jce.v4i2.256

Nash, R., et el. (2020). How Did Parents View the Impact of the Curriculum-Based HealthLit4Kids Program Beyond the Classroom?. Int J Environ Res Public Health. 2020 Feb; 17(4): 1449.

Trisnani, N. Introduction to Digital Literation of Line Mathematics for Violent Private Vocational School Students Private Vocational School. Buletin Udayana Mengabdi, [S.I.], v. 19, n. 3, p. 364-370, aug. 2020.

United Nations Children's Fund. (2020). Protecting children and adolescents with disabilities from the pandemic COVID-19 and children with disabilities in Europe and Central Asia. https://www.unicef.org/eca/protecting-children-and-adolescents-disabilities-pandemic. Accessed 10 May 2020.

Wang, C., et al. (2020). Immediate psychological responses and associated factors during the initial stage of the 2019 coronavirus disease (COVID-19) epidemic among the general population in China. International Journal of Environmental Research and Public Health, 17(5), 1729. doi:10.3390/ijerph17051729.

Wang, G., et al. (2020). Mitigate the effects of home confinement on children during the COVID-19 outbreak. The Lancet, 395(10228), 945-947. https://doi.org/10.1016/S01406736(20)30547$\underline{\mathrm{X}}$.

Wardani, A., \& Ayriza, Y. (2020). Analisis Kendala Orang Tua dalam Mendampingi Anak Belajar di Rumah Pada Masa Pandemi Covid-19. Jurnal Obsesi : Jurnal Pendidikan Anak Usia Dini, 5(1), 772. https://doi.org/10.31004/obsesi.v5i1.705.

Wiresti, R. D. (2020). Analisis Dampak Work From Home pada Anak Usia Dini di Masa Pandemi Covid-19. Jurnal Obsesi: Jurnal Pendidikan Anak Usia Dini, 5(1), 641. https://doi.org/ 10.31004/obsesi.v5i1.563.

Yuliawan, T. P. (2016). Coaching Psychology: Sebuah Pengantar. Buletin Psikologi. V. 19(2), 4554. https://doi.org/10.22146/bpsi.11556. 